\title{
Comunicação: um novo olhar para a sociedade educativa
}

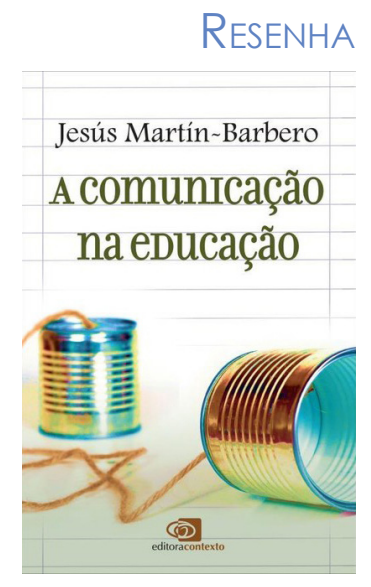

L Sueli Fernandes Ferreira Bernardi

Mestranda do Programa de Pós-graduação em Comunicação da Universidade Municipal de São Caetano do Sul. Professora da rede privada e da rede pública de ensino do Estado de São Paulo. E-mail: bernardisueli@gmail.com.

A comunicação na educação, o novo livro de Jesús Martin-Barbero (editora Contexto), traz um novo olhar a temas que percorrem as questões e questionamentos sobre comunicação e a educação e seus desdobramentos no panorama atual. Segundo o autor, a obra "pode ajudar a não se perder nos detalhes ou nas apreciações mais conjunturais e polêmicas" sobre a educação.

Barbero deixa claro, em suas reflexões, que o modelo escolar na atualidade encontra-se ultrapassado no espaço e no tempo. Afirma, além disso, que pode-se aprender também em fábricas, hospitais, empresas, enfim, em todos os lugares. $\mathrm{O}$ aprendizado acontece, também, em qualquer tempo. Um exemplo disso são os 20 mil idosos na Espanha com idade entre 60 e 85 anos que estudam em programas universitários. Essa nova acepção constitui um experimento do modelo de aprendizagem que se deve a demandas da sociedade em rede. Segundo o autor, "estamos passando de uma sociedade com sistema educativo a uma sociedade educativa".

Na primeira parte do livro, Alfabetizar em comunicação, o filósofo revisita alguns conceitos da pedagogia de Paulo Freire, seu objeto de estudo desde 1970. Postula o projeto de investigação em que a comunicação é pensada por meio da cultura, apoiado pela análise dos estudos freirianos e de Gramsci, os quais, segundo o autor, o motivaram a pensar a comunicação como um processo social e, ao mesmo tempo, a identificá-la como batalha social.

O autor afirma que a cultura do silêncio de Paulo Freire coexiste na educação atual. Explica que um povo, quando impedido de falar, não expressa sua linguagem, sua

$132 \frac{\text { Comunicação \& Inovação, PPGCOM/USCS }}{\text { v. 16, n. } 30 \text { (132-134) jan-abr } 2015}$ 
cultura. Dentro desse contexto, a escola é vista como uma "nova religião" ou salvação, onde uma pequena minoria se salva e os outros são estigmatizados e forçados a adaptar-se. Portanto, em sua visão, a cultura escolar favorece e prolonga a cultura do silêncio.

Interessa ressaltar a comparação que o autor faz em relação à crítica de Freire de que o indivíduo é aceito ou não em um grupo social por meio da linguagem - a instalação em um sistema de coisas a partir do sistema das palavras.

$\mathrm{Na}$ segunda parte do livro o autor expõe o dualismo entre o livro e o audiovisual: no primeiro, encontra-se o pensamento crítico, ou seja, do argumento, da reflexão; já o segundo, é reduzido à elaboração primária e irracional do pensamento. Barbero argumenta que o olhar que se tem para a mídia televisiva deve ser mudado, pois a TV causa um fascínio que, na maioria das vezes, é representado nos discursos políticos, escolares e culturais. Afirma, ainda, que é necessário explicar para transformar, isto é, negar a disseminação dos meios audiovisuais não soluciona o problema, ao contrário, seria mais proveitoso utilizá-los para explicar e informar.

O desafio lançado pelo autor em suas reflexões é o de pensar em um sistema educativo capaz de absorver as mudanças culturais atuais, formando cidadãos com habilidades em diferentes modos de aprender: leitura em livros, jornais impressos, jornais televisivos, quadrinhos, videoclipes e hipertextos. O autor complementa que as escolas não estão preparadas para a real inserção das novas tecnologias, que parecem ser utilizadas como fachada para a modernidade - instrumento - e não para a construção de uma estratégia para o conhecimento.

Dentro desse tais desafios deslocam o livro do patamar de figura central do saber, agora disseminado pelo texto eletrônico - hipertexto. Essa nova configuração muda um modelo inteiro de aprendizagem: linearidade sequencial da esquerda para a direita e de cima para baixo. Um outro viés seria o espaço-tempo para a aprendizagem: numa aprendizagem continuada ou ao longo da vida, os saberes transmitidos na escola agora se cruzam com os saberes do ambiente tecnocomunicativo.

A quarta e última parte aparece pela primeira vez na edição brasileira. Barbero expõe alguns dados de pesquisas feitas na América Latina com o viés nos novos modelos de comunicação escolar. São apresentados ao leitor alguns parâmetros, como o de privilegiar as narrativas orais para que não haja perda da identidade, novas formas de se estar junto em que se valorizam outros espaços que não somente as áreas demarcadas da escola para que a educação se comunique com os jovens.

Os questionamentos de Barbero encontrados nas páginas finais da obra mostram muito bem a magnitude da reflexão acerca da comunicação na educação: "Como a educação poderia assumir os novos desafios senão deixando-se interpelar, questionar e refundar 
por processos em que aquilo que fala e desafia a escola" [...] são, na verdade, "outros modos de estar juntos, de outra sociabilidade e outra sensibilidade.” Dessa forma, a chave para o mapa-projeto tracejado pelo filósofo estaria em "converter a Educação em espaço estratégico de cruzamento e interação entre as diversas linguagens, culturas e escrituras que povoam a rua e a casa, o mundo do trabalho e da política, pois só então a escola poderá ser o lugar de abertura (e de reconhecimento) ao outro e aos outros."

MARTIN-BARBERO, Jesus. A comunicação na educação. São Paulo: Contexto, 2014, 155 p. 